\title{
Examining Primary School Teachers' Attitudes Towards Distance Education in the COVID-19 Period $^{1}$
}

\author{
Halit Karalar, (Asst. Professor) \\ Muğla Sitkı Koçman University, Turkey \\ Sabri Sidekli, (Professor) \\ Muğla Sitkı Koçman University, Turkey
}

\begin{abstract}
Due to pandemic effects all over the world, the sudden switch to distance education has doubtlessly affected primary schools more adversely in education. Concerning the pandemic period, this study aimed to examine primary school teachers' attitudes on distance education. More specifically, the survey study with 173 primary school teachers' participation examined whether teachers' attitudes towards distance education have a meaningful difference in terms of gender, age, and teaching experience. The data which was collected via the "Attitude Scale on Distance Education" were analyzed through independent samples t-test and one-way analysis of variance (ANOVA). The results showed that there was no statistically significant difference between gender and primary school teachers' attitudes towards distance education; however, there is a statistically significant difference according to age and teaching experience. In addition, primary school teachers' attitudes towards distance education were negative. The possible reasons for these results were discussed and some implications were presented for research, practice, and policymakers.
\end{abstract}

Keywords: Attitudes towards distance education, primary school teachers, distance education, attitudes, COVID -19, pandemic

\section{Introduction}

After the announcement on COVID-19 as a global pandemic by World Health Organization on 11 March 2020 (WHO, 2020), governments had to make some strategic decisions on educational fields like all others in the world. To control the COVID-19 pandemic and overcome this period with minimum negative side effects, educational institutions have been closed up temporarily in many countries. According to the stated data on 2 April, 2020 of the United Nations Educational Scientific and Cultural Organization (UNESCO, 2020), 1.5 billion students ( $85 \%$ of the total number) have been affected in 172 countries in this period. To continue in teaching-learning activities, distance education, which has been previously used for assisting face-to-face education, has been the major alternative for compulsory education instead of classbased instructions in K-12 and higher education.

In public schools in Turkey, face-to-face education was discontinued on 13 March 2020. Ministry of National Education (MoNE), firstly, announced that the mid-term break that was planned in 6-10 April would be in 16-20 March; and there would be immediate distance education

\footnotetext{
* This study' results were presented as an oral presentation at the International Symposium on Global Pandemics and Multidisciplinary Covid-19 Studies
} 
activities starting on 23 March 2020 (Arslan \& Şumuer, 2020) with 18.108 .860 students and 1.077.307 teachers in Turkey (Demir \& Kale, 2020). Thanks to the Increasing Opportunities and Improvement of Technology project (known as FATIH project in Turkey) that was started in 2016 by MoNE, fiber internet background has been set up all around the country and it helped to cover the COVID-19 pandemic period with minimum harm. In the scope of this project, an internet connection was supplied in approximately 13.800 schools in Turkey (MoNE, 2020). Furthermore, Education Informatics Network (known as EBA in Turkey) that was designed in this project was also used as the major instrument for distance education in the pandemic. This instrument included Zoom online conference software so that online classes were smoothly organized and accessed by teachers and students. Furthermore, students could reach the materials, assignments, and activities which were designed by teachers on this platform. Additionally, EBA TV channels were organized by MoNE and students could follow the lectures on TV. Between the dates 23 March 2020 and 19 June 2020 (the final date of spring semester), TRT EBA TV Primary School, TRT EBA TV Secondary School, and TRT EBA TV High School channels telecasted 2.516 hours of lecture (Arslan \& Şumuer, 2020) and all of these courses were also available on EBA platform. As a result, thanks to the FATIH project, the Turkish education system has reached a network to overcome the negative side effects caused by the COVID-19 pandemic.

Distance education is not a new concept, though. About 300 years ago, weekly stenography education was sent by mail in the USA and it was presented as distance education; however, the first institution, which applied distance education in 1858 was the University of London (Clark, 2020). Distance education can be defined as "teaching and planned learning in which teaching normally occurs in a different place from learning, requiring communication through technologies as well as a special institutional organization" (Moore \& Kearsley, 2012, p. 2). Distance education can also be defined as "institution-based formal education where the learning group is separated, and where interactive telecommunication systems are used to connect learners, resources, and instructors" (Schlosser et al., 2009, p. 1). Even if there are some differences in the definitions, there should be four basic components in distance education (Simonson et.al., 2015) namely: (1) Distance education is an institutional action, (2) students and teachers are separated temporarily and physically; communication can be asynchronous or synchronous, (3) media tools such as television, phone or internet are applied for interaction between student-student, student-teacher, and student-material, but are not limited to electronic media, (4) teachers should be interactive, and related materials and/or sources that are necessary for education should be accessible anywhere anytime.

Distance education has two modes: synchronous and asynchronous (Clark, 2020). Asynchronous mode refers to distance education in which students can access learning materials anytime, and they focus on learning individually. The core of asynchronous mode is supported by learning management systems (Moodle, Blackboard, Sakai, etc.). Synchronous mode, on the other hand, refers to the distance education that is planned and practiced by teachers and students in different places at the same time, thanks to integrated conference management software (Zoom, Adobe Connect, Microsoft Teams, BigBlueButton, etc.) in Learning Management System.

Due to pandemic effects all over the world, the sudden switch to distance education has doubtlessly affected primary schools more adversely in education. Considering the developmental stages of primary school students, they are in the concrete operational stage and need concrete learning experiences, materials, and physical games; however, education in a virtual platform that may not be suitable for students' developmental stages has become a current issue. Relatively, teachers who do not have any experience in distance education had to deal with many struggles in this period as well. In Switzerland, a conducted study on primary and secondary school students' language and math performance after 8 weeks of distance education in the pandemic period, showed that secondary school students have not been adversely affected by distance education, while the academic performance of primary school students has been fallen by half (Tomasik et. al., 2020). 
Though there is limited study on distance education practice in primary schools (Hilli, 2020), there have been many attempts to understand the effects of distance education during the pandemic in primary schools. In the related literature, there are some studies reflecting the ideas of primary school teachers, primary school students, and parents on distance education in the pandemic (F. Demir \& Özdaş, 2020; Yurtbakan \& Akyıldız, 2020), the satisfaction of primary school teachers on distance education (Korucuk, 2020), parents' opinions about students' experiences (Erol \& Erol, 2020; İnci-Kuzu, 2020), the suitability of primary school curricula for distance education (Koç, 2021). Although there are some studies regarding in-service teachers' attitudes (Ağır et, al., 2007; Uzunboylu, 2007; Yahşi \& Kırkıç, 2020) and pre-service teachers' attitudes (Bayram et, al., 2019; Halitoğlu, 2021; Yenilmez et.al., 2017) on distance education in different subject-specifics, the concerned studies are still limited to focus particularly on primary school teachers' attitudes towards distance education.

In addition to literature based gap, there are three barriers to distance education/e-learning (Panda \& Mishra, 2007) widely known as: (1) personal barriers (lack of knowledge, skills, training, role-models and time), (2) attitudinal barriers (not believing technology, unwillingness for technology use, anxiety on student communication) and (3) organizational barriers (insufficient technical support, equipment, software, teaching design and not knowing the value of online education). In these barriers, attitudinal prejudices are some of the most important barriers for the efficacy and transferability in the distance education (Ağır et al., 2007; Panda \& Mishra, 2007; Yahşi \& Kırkıç, 2020). Within this scope, as a keystone of educational changes, studying primary school teachers' attitudes towards distance education in the pandemic is significant for both getting success on distance education and presenting empirical evidence for policymakers and practitioners' decisions in the following procedures. Consequently, this study aimed to determine the primary school teachers' attitudes towards compulsory distance education in pandemic and the following questions are attempted to be answered:

- What are the primary school teachers' attitudes towards compulsory distance education in pandemic period?

- Is there any statistically significant difference in the primary school teachers' attitudes towards compulsory distance education during pandemic in terms of gender?

- Is there any statistically significant difference in the primary school teachers' attitudes towards compulsory distance education during pandemic in terms of age?

- Is there any statistically significant mean difference in the primary school teachers' attitudes towards compulsory distance education during pandemic in terms of teaching experience?

To address these questions, the researchers collected data from 173 primary school teachers. Independent samples t-test and one-way analysis of variance (ANOVA) were used to analyze the data. The research seeks to add to the growing diversity of global knowledge in primary school and distance education in the COVID-19 pandemic.

\section{Method}

\section{Research Model}

Survey model is used in studies that aim to determine participants' ideas, interests, skills, attitudes, etc. on a specific research field (Büyüköztürk et.al., 2009) for the aim of describing characteristic features of participants both individually and in groups (Fraenkel et.al., 2012). In this descriptive research, a survey model is used to examine the primary school teachers' attitudes towards distance education. 


\section{Participants}

The research was conducted with the participation of 173 in-service primary school teachers working in public schools in one of the western provinces of Turkey. Not all participants had previous teaching experience of distance learning of adult or children students, rather they had face-to-face teaching experience. Since this study was conducted in the pandemic, the convenience sampling method was preferred to reach participants. Table 1 shows the demographic information of voluntarily and willingly participated teachers.

\begin{tabular}{llll}
\hline \multirow{3}{*}{ Gender } & & $f$ & $\%$ \\
\hline \multirow{4}{*}{ Age } & Female & 130 & 75.1 \\
& Male & 43 & 24.9 \\
& Total & 173 & 100 \\
\hline \multirow{3}{*}{ Teaching } & $21-31$ & 112 & 64.7 \\
Experience & $32-41$ & 21 & 12.1 \\
& $42+$ & 40 & 23.1 \\
& Total & 173 & 100 \\
\hline
\end{tabular}

Table 1. Demographic Information of Participants

\section{Data Collection Tools}

As for data collection instruments in the study, the personal information form designed by the researchers was used to get the demographic information of participants. To determine the attitudes of participants towards distance education, the "Attitude Scale Towards Distance Education" developed by (Ağır et.al., 2007) was used. This scale consists of two sub-dimensions and 21 items in total; it is designed as a five-point Likert-scales, namely, strongly disagree (1) to strongly agree (5). The scale consists of seven negative items. The lowest point that can be obtained from this scale is 21 ; the highest point is 105 . The first sub-dimension is "The advantages of distance education", with the lowest point as 14, the highest point as 70 . The second sub-dimension is "The limitations of distance education", with the lowest point as 7, the highest point as 35 . Cronbach Alpha reliability coefficient was calculated as 0.835 for this scale (Ağır et. al., 2007). In this study, the Cronbach Alpha reliability coefficient was calculated as 0.85 for the first subdimension (The Advantages of Distance Education), and 0.75 for the second sub-dimension (The Limitations of Distance Education), and 0.85 on the total scale.

\section{Data Collection}

The scale was converted into a Google Form, and the access link was shared with 215 inservice primary school teachers via social media as Facebook, Instagram, and WhatsApp groups. In this form, teachers were informed about the research and it was announced that participation in the study was voluntary. The form was filled out by the 173 teachers within three weeks. The response rate of the scale was $80.5 \%$, indicating an acceptable rate. When the responses stopped increasing, the data collection phase was completed and the data analysis phase was initiated. Since the form was digital and each question had to be answered, the data were obtained without any errors and missing values. 


\section{Data Analysis}

To determine the statistical tests for data analysis, firstly, normal distribution rates of the data were examined. Since the coefficient of Kurtosis and Skewness scores of sub-dimensions and total scale were calculated between -1 and +1 (see Table 2), it was seen that there was no mean deviation in normal distribution scores (Hair et al., 2019). Since group scores and variances were normally distributed, independent samples t-test and one-way analysis of variance (ANOVA) test were used to analyze mean differences. Since the groups do not have an equal number of participants, the Scheffe test as one of the Post-Hoc Tests was used for mean differences between group average scores.

Cohen's $d$ was used to report the effect sizes of the significant differences found in the results of the $t$-test and Scheffe test. The effect size values of $0.20,0.50$, and 0.80 were interpreted as small, medium, and large, respectively (Cohen, 1992). Also, 95\% confidence intervals of the found effect sizes were given to provide additional evidence in effect sizes. Eta squared $\left(\eta^{2}\right)$ was used to report the effect sizes of the significant differences according to results of ANOVA. The effect sizes values of $0.01,0.06$, and 0.14 were interpreted as small, medium, and large, respectively (Büyüköztürk, 2015).

The collected data were analyzed via the Jamovi program (The Jamovi Project, 2020). It was purposefully selected since it is a free and user-friendly software that uses $\mathrm{R}$ statistical program (R Core Team, 2019). In the data analysis process, the significance level is determined as .05 in this study.

\section{Results}

\section{Primary School Teachers' Attitudes Towards Distance Education}

The descriptive data of sub-dimensions and total scores on primary school teachers' attitudes in the Attitude Scale on Distance Education are presented in Table 2.

\begin{tabular}{lllllllll}
\hline & Item & $\mathrm{N}$ & $\mathrm{M}$ & $\mathrm{SD}$ & $\mathrm{Min}$ & Max & Skewness & Kurtosis \\
\hline ADE & 14 & 173 & 38.4 & 10.6 & 14 & 65 & -0.12 & -0.26 \\
LDE & 7 & 173 & 14.9 & 5.0 & 7 & 30 & -0.56 & 0.53 \\
Total & 21 & 173 & 53.3 & 13.0 & 21 & 84 & -0.34 & -0.17 \\
\hline
\end{tabular}

Table 2. Descriptive Findings on Attitude Scale toward Distance Education Scores

Note. ADE: Advantages of Distance Education, LDE: Limitations of Distance Education

Primary school teachers' average scores on the "Advantages of Distance Education" were calculated as 38 and this value was lower than the general average (52) considering the total range (14 to 70) for this scale. This finding means that primary school teachers had negative attitudes on the advantages of distance education. Additionally, primary school teachers' average scores on the sub-dimension, namely the "Limitations of Distance Education", were calculated as approximately 15 and this value was lower than the general average (21) considering the total range (7 to 35) for this scale. This finding means that there are some limitations in distance education according to primary school teachers. The average of total scores was nearly 53 for this study and this value was lower than the general average (63) considering the total range (21 to 105) of the scale, indicating primary school teachers had negative attitudes towards distance education. To sum up, primary school teachers think that there are some limitations in distance education and it may not be very advantageous; therefore, they may have negative attitudes towards distance education. 


\section{Primary School Teachers' Attitudes Towards Distance Education in terms of Gender}

Table 3 presents the descriptive data of sub-dimensions and total scores on primary school teachers' attitudes in the Attitude Scale on Distance Education and t-test results in terms of their gender. There was no significant difference between genders. It shows that gender is not a significant factor in attitudes towards distance education.

\begin{tabular}{|c|c|c|c|c|c|c|c|}
\hline & & $\mathrm{N}$ & $\mathrm{M}$ & SD & $\mathrm{df}$ & $t$ & $p$ \\
\hline \multirow{2}{*}{$\begin{array}{l}\text { Advantages of } \\
\text { Distance Education }\end{array}$} & Female & 130 & 38.60 & 10.55 & 171 & 0.45 & 0.65 \\
\hline & Male & 43 & 37.80 & 10.89 & & & \\
\hline \multirow{2}{*}{$\begin{array}{l}\text { Limitations of } \\
\text { Distance Education }\end{array}$} & Female & 130 & 14.90 & 4.81 & 171 & 0.02 & 0.99 \\
\hline & Male & 43 & 14.90 & 5.41 & & & \\
\hline \multirow{2}{*}{ Total } & Female & 130 & 53.50 & 12.80 & 171 & 0.37 & 0.71 \\
\hline & Male & 43 & 52.70 & 13.77 & & & \\
\hline
\end{tabular}

Table 3. T-test results of Attitude Scale towards Distance Education Scores in terms of Gender

\section{Primary School Teachers' Attitudes Towards Distance Education in terms of Age}

Table 4 presents the descriptive data of sub-dimensions and total scores on primary school teachers' attitudes in Attitude Scale on Distance Education, and one-way variance analysis (ANOVA) results in terms of their age. There was a significant difference in the average scores of the scale $(F=5.41, p<.01)$ in terms of age with medium effect $\left(\eta^{2}=0.06\right)$. As for the subdimensions of this study, there was a significant difference in the "Advantages of Distance Education" with medium effect $\left(\eta^{2}=0.07\right)$ for the general results $(F=6.54, p<.01)$; however, there was no significant difference in the "Limitations of Distance Education" $(F=1.78, p>.05)$. On the contrary, in all age groups, the participants had similar negative attitudes towards the limitations of distance education.

\begin{tabular}{|c|c|c|c|c|c|c|c|c|c|}
\hline & \multicolumn{2}{|c|}{$\begin{array}{l}\text { Ages } \\
(\mathrm{n}=112)\end{array}$} & \multicolumn{2}{|c|}{$\begin{array}{l}\text { Ages } \\
(n=21)\end{array}$} & \multicolumn{2}{|c|}{$\begin{array}{l}\text { Ages } \\
(n=40)\end{array}$} & \multirow[b]{2}{*}{$F$} & \multirow[b]{2}{*}{$p$} & \multirow[b]{2}{*}{$\begin{array}{l}\text { Scheffe } \\
\text { test }\end{array}$} \\
\hline & Mean & SD & Mean & SD & Mean & SD & & & \\
\hline $\mathrm{ADE}$ & 40.1 & 9.8 & 39.5 & 12.3 & 33.3 & 10.6 & 6.54 & 0.00 & $\begin{array}{l}1>2 \\
2>3\end{array}$ \\
\hline LDE & 15.3 & 4.8 & 13.2 & 4.6 & 14.4 & 5.4 & 1.78 & 0.17 & --- \\
\hline Total & 55.4 & 11.8 & 52.7 & 14.5 & 47.7 & 14.5 & 5.41 & 0.00 & $1>3$ \\
\hline
\end{tabular}

Table 4. An Analysis of Distance Education Attitude and Age

Note. ADE: Advantages of Distance Education, LDE: Limitations of Distance Education 
The reason for the mean difference between the score of the Attitude Scale on Distance Education and the scores of sub-dimensions were examined via the Scheffe test as one of the PostHoc Tests. There was a mean difference in favor of the 21-32 age group with medium effect (Cohen's $d=0.66)$ when it is compared with the $42+$ age group in general $(t=3.28, \mathrm{p}<.01)$. These findings show that primary school teachers who are 21-32 years old had more positive attitudes towards distance education than primary school teachers who are $42+$ years old, and there was no significant difference among other age groups. In the sub-dimension on the "Advantages of Distance Education", there was a significant mean difference in favor of 21-32 age group with medium effect (Cohen's $d=0.60$ ) when it was compared with $42+$ age group participants' scores $(t=3.58, p<.01)$. However, even if there was no significant difference between 32-41 and 42+ age groups $(t=2.24, p>.05)$, it can be accepted that there was a mean difference in favor of 3241 age groups with medium effect (Cohen's $d=0.60$ ) since there was no 0 value [0.07 - 1.14] in $95 \%$ confidence interval range scores. All of these findings state that the positive attitudes towards the "Advantages of Distance Education" are getting lower when the age of participants gets older. Besides, the most negative attitudes were seen in $42+$ age group participants.

\section{Primary School Teachers' Attitudes Towards Distance Education in terms of Teaching Experience}

Table 5 shows the descriptive data of sub-dimensions and total scores on primary school teachers' attitudes in Attitude Scale on Distance Education and one-way variance analysis (ANOVA) results in terms of their teaching experience.

\begin{tabular}{|c|c|c|c|c|c|c|c|c|c|}
\hline & \multicolumn{2}{|c|}{$\begin{array}{l}\text { Years } \\
(\mathrm{n}=108)\end{array}$} & \multicolumn{2}{|c|}{$\begin{array}{l}\text { Years } \\
(\mathrm{n}=27)\end{array}$} & \multicolumn{2}{|c|}{$\begin{array}{l}\text { Years } \\
(\mathrm{n}=38)\end{array}$} & \multirow[b]{2}{*}{$F$} & \multirow[b]{2}{*}{$p$} & \multirow[b]{2}{*}{$\begin{array}{l}\text { Scheffe } \\
\text { test }\end{array}$} \\
\hline & Mean & SD & Mean & SD & Mean & SD & & & \\
\hline $\mathrm{ADE}$ & 40.4 & 9.7 & 35.9 & 9.2 & 33.9 & 12.5 & 5.72 & 0.00 & $\begin{array}{l}1>3 \\
1>3\end{array}$ \\
\hline LDE & 15.5 & 4.7 & 13.2 & 5.1 & 14.7 & 5.0 & 3.10 & 0.04 & $1>2$ \\
\hline Total & 55.9 & 11.7 & 49.2 & 15.1 & 48.6 & 12.6 & 6.25 & 0.00 & $\begin{array}{l}1>3 \\
1>3\end{array}$ \\
\hline
\end{tabular}

Table 5. An Analysis of Distance Education Attitude and Teaching Experiences

Note. ADE: Advantages of Distance Education, LDE: Limitations of Distance Education

As seen in Table 5, there was a significant mean difference $\left(F=6.25, p<.01, \eta^{2}=0.07\right)$ on the average scores of the scale in terms of teaching experiences with medium effect. For the sub-dimensions of this study, there was a significant difference $\left(F=5.72, p<.01, \eta^{2}=0.06\right)$ in the "Advantages of Distance Education" with medium effect. For the "Limitations of Distance Education", there was a significant mean difference $\left(F=3.10, p<.05, \eta^{2}=0.04\right)$ with medium effect.

The reason for the mean difference between the total scores of the Attitude Scale on Distance Education and sub-dimensions was examined via the Scheffe test. There was a significant mean difference in favor of 1-7 years in teaching experience with medium effect (Cohen's $d=$ $0.54)$ when it was compared with $8-14$ years $(t=2.84, p<.05)$. There was a significant mean difference again in favor of 1-7 years with medium effect (Cohen's $d=0.54$ ) when it was compared with $15+$ years $(t=2.70, p<.05)$. These findings show that primary school teachers who have 
been teaching for 1-7 years had more positive attitudes towards distance education than others with 8-14 and 15+ teaching experience, and there was no significant difference between 8-14 and 15+-years groups.

According to Scheffe test results, the mean difference between average scores of the "Advantages of Distance Education" can be explained with the mean difference in favor of 1-7 years in the teaching experience group with medium effect (Cohen's $d=0.63$ ) when it is compared with $15+$ years group participants' scores $(t=2.94, p<.05)$. Even if there was no significant difference between the 1-7 and 8-14 years' group $(t=2.30, p>.05)$, since there is no 0 value [0.06 -0.81 ] in $95 \%$ confidence interval range scores the significant mean difference in favor of the 1-7 years' group with medium effect (Cohen's $d=0.43$ ) was acceptable. All of these findings state that the positive attitudes towards the "Advantages of Distance Education" are getting lower when the participants' years in teaching experience increase. The most negative attitudes were seen in $15+$ years of teaching experience.

The mean difference between average scores of "Limitations of Distance Education" can be explained with the significant difference in favor of 1-7 years of teaching experience group with medium effect (Cohen's $d=0.47$ ) when it is compared with 8-14 years $(t=2.48, p<.05)$. It reflects that teachers with 8-14 years teaching experience considered distance education as limited when they are compared with other teaching experience groups.

\section{Discussion}

Politics and policymakers tend to use technology as a tool in problem-solving when struggling in educational systems, and this tendency does not change in this suffering period. Distance education takes a crucial role in the pandemic period to prevent problems in closed-up schools. This study aimed to search the attitudes of primary school teachers who have been highly affected by this compulsory distance education in pandemic. More specifically, with the participation of 173 primary school teachers, it was examined that whether there is a significant difference on attitudes towards compulsory distance education regarding age, gender, and teaching experience of primary school teachers.

The study concluded that primary school teachers have negative attitudes towards the advantages of distance education. Relatively, they think that distance education offers limited teaching experience in this period. This finding is contrasted to many studies in the related literature (Halitoglu, 2021; Yahşi \& Kırkıç, 2020; Yenilmez et al., 2017). However, the participant group is limited to primary school teachers, and students in this level of education are in the concrete operational stage. These antecedents may result in similar and/or different teaching challenges experienced by different subject areas. Therefore, the findings should be discussed within this perspective. The barriers which are experienced by the primary school teachers on distance education in the pandemic are used in classifying the primary and secondary barriers in technology integration in education (Ertmer, 1999).

The experienced primary barriers in distance education can be summarized as inappropriate course contents with unattainable objectives, lack of feedback and ineffective communication in distance education (S. Demir \& Kale, 2020); distractions of environmental factors (Arslan \& Şumuer, 2020; S. Demir \& Kale, 2020, İnci-Kuzu, 2020); lower levels of motivation, technical inaccessibility (Arslan, Şumuer, 2020; F. Demir \& Özdaş, 2020; S. Demir \& Kale, 2020; Fidan, 2020); insufficient assessment tools, problems in displaying current courses in EBA TV, limited time for online courses (F. Demir \& Özdaş, 2020); problems in the use of EBA TV (Özdaş, 2020).

The secondary barriers are based on teacher related reasons. These barriers can be summarized, considering distance education, as lack of preparation (Fidan, 2020; Özdoğan \& Berkant, 2020); lack of experience and knowledge (the lack of knowledge and skills), pressure in self-improvement (S. Demir \& Kale, 2020), and limited activities (F. Demir \& Özdaş, 2020). All 
of these barriers can explain the reasons for the negative attitudes of primary school teachers in distance education.

Furthermore, stated barriers are not only observed in Turkey. The conducted study in Hong Kong (Lau \& Lee, 2020) reported that primary school students were not be able to complete the tasks individually. The report emphasizes that they needed to have much more materials to learn interactively, had problems in getting motivated and engaged in the courses, had concentration problems due to their parents, and had some technical and supplementary problems in this period. In another study conducted in Switzerland (Tomasik et.al., 2020), conclusions indicated that middle school students were not highly affected in this period when compared with primary school students. The results remark that primary school students' learning performance decreased to half in distance education compared to face-to-face education. In a similar finding by Erol and Erol (2020), it was noticed that the academic success of primary school students got lower in the distance education period and their parents had not mediated the individual learning successfully.

When the attitudes of primary school teachers were examined in terms of their gender, similar to the related literature (Halitoglu, 2021; Öneri-Uzun et al., 2020; Yahşi \& Kırkıç, 2020), gender has not been a significant variable for the attitudes, since the mentioned barriers are experienced by both male and female teachers.

Concerning teaching experience, there was a significant mean difference in the attitudes of primary school teachers. The results showed that 1-7-year experienced teachers have more positive attitudes towards distance education than 8-14 or 15+ years. Also, as teaching experience has increased, the positive attitudes towards the advantages of distance education have been getting lower. 8-14-year experienced teachers stated more limitations resulting from distance education than 1-7-year ones. This finding supports previous studies in the literature (Uzunboylu, 2007; Yahşi \& Kırkıç, 2020). These studies briefly explain that teachers in their early carriers have more positive tendencies to benefit from distance education.

Conclusions from primary school teachers' attitudes regarding age showed that there was a significant mean difference. The study explained that 21-32-year old primary school teachers had more positive attitudes towards distance education than $42+$-year old teachers. As the age is getting older, positive attitudes are decreasing. Besides, the most negative attitudes are placed in the group of 42+-year old teachers. However, there was not a significant difference in the attitudes of primary school teachers about the limitations of distance education in terms of their age. The reason for this may be that young teachers take classes with more up-to-date instructional technologies and distance education in their initial teacher education. Indeed, respectively young teachers are exposed to courses practiced through distance education so that they are more familiar with its function. To exemplify, Paydar and Doğan (2019) examined the opinions of pre-service primary school teachers on distance education, and concluded that they generally had positive opinions and ideas on distance education. Connectedly, another study conducted with 236 candidate teachers from different disciplines concluded that candidate teachers' attitudes had a generally positive on distance education (Halitoğlu, 2021).

\section{Implications for Research, Practice, Policymakers}

The results of this study show that younger and low-experienced primary school teachers have more positive attitudes towards distance education in the pandemic than older and experienced ones. Therefore, it is suggested to practice blended learning in which younger teachers continue with distance education, and 45-65-year-old teachers sustain face-to-face teaching activities during the pandemic. In this way, the work load on distance education can be decreased and the huge pressure on older teachers can be controlled. Even the COVID-19 pandemic is over; future threats resulting from destroying forests can trigger new pandemic (Snowden, 2019). To be chary for these kinds of new pandemics, it is suggested that policymakers should create new policies as precautions for primary and secondary technology based barriers. After the pandemic, 
if policymakers, researchers, and practitioners want primary school teachers to use technology effectively in their classrooms, they should overcome the secondary barriers which are more significant for technology integration (Ertmer, 1999; Hew \& Brush, 2007). Several studies which are based on the technology acceptance model (TAM), the theory of planned behavior (TPB), and related theories show that the beliefs and attitudes of users are effective on the aim of using technology and attitudes toward it (Davis, 1989). In this sense, it is suggested to increase the positive attitudes of primary school teachers towards distance education. To do so, there can be professional development programs on distance education with contents including primary school students' developmental stages. Teachers can be grouped according to age and teaching experience, then a professional development program can be practiced referring to these groups. The beliefs, attitudes, intentions, and usage of technology can change in time depending on individual experiences and learning (Bhattacherjee \& Premkumar, 2004). Therefore, to follow the changes in primary school teachers' attitudes towards distance education, it is suggested to conduct similar studies on this field, designed periodically to get information about the attitudes of primary school teachers towards distance education.

\section{Limitations of the Study}

Research findings are limited to a certain extend. The number of primary school teachers is small; therefore, the generalizability is low. This means that findings cannot be interpreted to reflect all primary school teachers in Turkey. However, research findings will make sense in understanding primary school teachers' attitudes towards distance education in the pandemic. Another limitation of the study is the high participation of young classroom teachers with little teaching experience. Similar studies can be conducted with more senior and more experienced teachers. 


\section{References}

Ağır, F., Gür, H., \& Okçu, A. (2007). Uzaktan eğitime karş1 tutum ölçeği geliştirmesine yönelik geçerlik ve güvenirlik çalışması. E-Journal of New World Sciences Academy, 3(2), 128-139.

Arslan, Y., \& Şumuer, E. (2020). Covid-19 döneminde sanal sinıflarda öğretmenlerin karşılaştıkları sınıf yönetimi sorunları. Milli Eğitim Dergisi, 49(1), 201-230. https://doi.org/10.37669/milliegitim.791453

Bayram, M., Peker, A. T., Aka, S. T., \& Vural, M. (2019). Üniversite öğrencilerinin uzaktan eğitim dersine karşı tutumlarının incelenmesi. Gaziantep Üniversitesi Spor Bilimleri Dergisi, 4(3), 330345. https://doi.org/10.31680/gaunjss.586113

Bhattacherjee, A., \& Premkumar, G. (2004). Understanding changes in belief and attitude toward information technology usage: A theoretical model and longitudinal test. Management Information Systems Quarterly, 28(2), 229-254.

Büyüköztürk, Ş. (2015). Sosyal bilimler için veri analizi el kitabı [Handbook of data analysis for social sciences] (21st ed.). Pegem Akademi.

Büyüköztürk, Ş., Kılıç Çakmak, E., Akgün, Ö. E., Karadeniz, Ş., \& Demirel, F. (2009). Bilimsel araştırma yöntemleri (3rd ed.). Pegem Akademi.

Can, E. (2020). Coronavirüs (Covid-19) pandemisi ve pedagojik yansımaları: Türkiye'de açık ve uzaktan eğitim uygulamaları. Açıköğretim Uygulamaları ve Araştırmaları Dergisi, 6(2), 11-53.

Cohen, J. (1992). A power primer. Psychological Bulletin, 112(1), 155-159.

Clark, J. T. (2020). Distance education. In Clinical Engineering Handbook (pp. 410-415). Elsevier. https://doi.org/10.1016/B978-0-12-813467-2.00063-8

Davis, F. D. (1989). Perceived usefulness, perceived ease of use, and user acceptance. MIS Quarterly, 13(3), 319-339. https://doi.org/10.2307/249008

Demir, F., \& Özdaş, F. (2020). Covid-19 sürecindeki uzaktan eğitime ilişkin öğretmen görüşlerininin incelenmesi. Milli Eğitim Dergisi, 49(1), 273-292.

https://doi.org/10.37669/milliegitim.775620

Demir, S., \& Kale, M. (2020). Öğretmen görüşlerine göre, Covid-19 küresel salgını döneminde gerçekleştirilen uzaktan eğitim sürecinin değerlendirilmesi. Journal of Turkish Studies, 15(8), 3445-3470. https://doi.org/10.7827/TurkishStudies.44492

Erol, M., \& Erol, A. (2020). Koronavirüs pandemisi sürecinde ebeveynleri gözünden ilkokul öğrencileri. Milli Eğitim Dergisi, 49(1), 529-551. https://doi.org/10.37669/milliegitim.766194

Ertmer, P. A. (1999). Addressing first- and second-order barriers to change: Strategies for technology integration. Educational Technology Research and Development, 47(4), 47-61. https://doi.org/10.1007/BF02299597

Fidan, M. (2020). Covid-19 belirsizliğinde eğitim: İlkokulda zorunlu uzaktan eğitime ilişkin öğretmen görüşleri. Uşak Üniversitesi Eğitim Araştırmaları Dergisi, 6(2), 24-43.

Fraenkel, J. R., Wallen, N. E., \& Hyun, H. H. (2012). How to design and evaluate research in education (8th ed.). McGraw Hill.

Hair, J. F., Blacks, W. C., Babin, B. J., \& Anderson, R. E. (2019). Multivariate data analysis (8th ed.). Cengage Learning.

Halitoglu, V. (2021). Attitudes of student teachers towards distance education within the context of Covid-19 pandemic. International Journal of Curriculum and Instruction, 13(1), 816-838.

Hew, K. F., \& Brush, T. (2007). Integrating technology into K-12 teaching and learning: current knowledge gaps and recommendations for future research. Educational Technology Research \& Development, 55(3), 223-252. https://doi.org/10.1007/s11423-006-9022-5

Hilli, C. (2020). Distance teaching in small rural primary schools: a participatory action research project. Educational Action Research, 28(1), 38-52.

https://doi.org/10.1080/09650792.2018.1526695

İnci-Kuzu, Ç. (2020). Covid-19 pandemisi sürecinde uygulanan ilkokul uzaktan eğitim programı (EBA TV) ile ilgili veli görüşleri. Milli Eğitim Dergisi, 49(1), 505-527.

https://doi.org/10.37669/milliegitim.720556

Koç, E. S. (2021). İlkokul öğretim programlarının Covid-19 sonrası yaygınlaşan uzaktan eğitime 
uygunluğunun incelenmesi. International Anatolia Academic Online Journal, 7(1), 24-36.

Korucuk, B. (2020). A study on the rating of distance education satisfaction factors from classroom teachers: An example of Giresun. Instructional Technology and Lifelong Learning, 1(2), 189-202. Lau, E. Y. H., \& Lee, K. (2020). Parents' views on young children's distance learning and screen time during COVID-19 class suspension in Hong Kong. Early Education and Development. https://doi.org/10.1080/10409289.2020.1843925

MoNE. (2020). Alt yap1 ve erişim hizmetleri. http://fatihprojesi.meb.gov.tr/altyapi-erisim.html Moore, M., \& Kearsley, G. (2012). Distance education: a system view of online learning (3rd ed.). Wadsworth.

Öneri-Uzun, G., Eş, A. Ç., \& Evram, G. (2020). Examination of attitudes of university students in distance education according to some variables. Near East University Journal of Education Faculty (NEUJEF), 3(2), 104-115.

Özdoğan, A. Ç., \& Berkant, H. G. (2020). Covid-19 pandemi dönemindeki uzaktan eğitime ilişkin paydaş görüşlerinin incelenmesi. Milli Eğitim Dergisi, 49(1), 13-43.

https://doi.org/10.37669/milliegitim.788118

Panda, S., \& Mishra, S. (2007). E-Learning in a Mega Open University: Faculty attitude, barriers and motivators. Educational Media International, 44(4), 323-338.

https://doi.org/10.1080/09523980701680854

Paydar, S., \& Doğan, A. (2019). Öğretmen adaylarının açık ve uzaktan öğrenme ortamlarına yönelik görüşleri. Eğitim ve Teknoloji, 1(2), 154-162.

R Core Team (2019). R: A Language and environment for statistical computing. (Version 3.6) [Computer software]. https://cran.r-project.org/.

Schlosser, L. A., Simonson, M., \& Hudgins, T. L. (2009). Distance education: Definitions and glossary of terms (3rd ed.). Information Age Publishing.

Simonson, M., Smaldino, S., \& Zvacek, S. (2015). Teaching and learning at a distance (6th ed.). Information Age Publishing.

Snowden, F. M. (2019). Epidemics and society: From the black death to the present. Yale University Press. https://doi.org/10.2307/j.ctvqc6gg5

The jamovi project (2020). Jamovi. (Version 1.2) [Computer Software]. https://www.jamovi.org Tomasik, M. J., Helbling, L. A., \& Moser, U. (2020). Educational gains of in-person vs. distance learning in primary and secondary schools: A natural experiment during the COVID-19 pandemic school closures in Switzerland. International Journal of Psychology. https://doi.org/10.1002/ijop.12728

UNESCO. (2020). COVID-19 impact on education.

https://en.unesco.org/covid19/educationresponse

Uzunboylu, H. (2007). Teacher attitudes toward online education following an online inservice program. International Journal on E-Learning, 6(2), 267-277.

WHO. (2020). WHO Director-General's opening remarks at the media briefing on COVID-19 -11 March 2020. https://www.who.int/director-general/speeches/detail/who-director-general-sopening-remarks-at-the-media-briefing-on-covid-19---11-march-2020

Yahşi, Ö., \& Kırkıç, K. A. (2020). Uzaktan eğitim sürecinde öğretmenlerin uzaktan eğitime yönelik tutumlarının incelenmesi. Turkish Studies-Educational Sciences, 15(5), 3827-3847. https://doi.org/10.47423/TurkishStudies.46136

Yenilmez, K., Balbağ, M. Z., \& Turgut, M. (2017). Öğretmen adaylarının uzaktan eğitime yönelik tutumlarının bazı değişkenler açısından incelenmesi. Erzincan Üniversitesi Eğitim Fakültesi Dergisi, 19(2), 91-107. https://doi.org/10.17556/erziefd.305902

Yurtbakan, E., \& Akyıldız, S. (2020). Sınıf öğretmenleri, ilkokul öğrencileri ve ebeveynlerin Covid-19 izolasyon döneminde uygulanan uzaktan eğitim faaliyetleri hakkındaki görüşleri. Journal of Turkish Studies, 15(6), 949-977. https://doi.org/10.7827/turkishstudies.43780 